\title{
Professional Development of a Teacher in the ICT Era
}

\section{Apriana Kusumaningrum, Suharno, and Triyanto}

Sebelas Maret University, Surakarta

\section{Abstract}

Teacher plays a significant role in educating. As an agent of change, the teacher should be perceptive to any change as the result of the modernism. It requires the teacher to possess more complex competence and idea. Therefore, competence development activities are needed for the teacher. The competence and professional development of teacher are expected to be able in improving the professional teacher quality and further improve the education quality. This research was aimed to describe the development of teacher profession in this ICT era. The method used was a literature study. The data from the research showed that 1) The professional development can be done through the activities within the working area, and 2) There are some factors

Corresponding Author: Apriana Kusumaningrum apriana2604@gmail.com

Received: 23 January 2019 Accepted: 26 February 2019 Published: 17 March 2019

Publishing services provided by Knowledge E

(c) Apriana Kusumaningrum et al. This article is distributed under the terms of the

Commons Attribution License, which permits unrestricted use and redistribution provided that the original author and source are credited.

Selection and Peer-review under the responsibility of the International Seminar on Language, Education, and Culture Conference Committee. affecting the teacher's professional development.

Teacher plays a significant role in educating. As an agent of change, the teacher should be perceptive to any change as the result of the modernism. It requires the teacher to possess more complex competence and idea. Therefore, competence development activities are needed for the teacher. The competence and professional development of teacher are expected to be able in improving the professional teacher quality and further improve the education quality. This research was aimed to describe the development of teacher profession in this ICT era. The method used was a literature study. The data from the research showed that 1) The professional development can be done through the activities within the working area, and 2) There are some factors affecting the teacher's professional development. Keywords: development, ICT era, professionalism, teacher.

Keywords: development, ICT era, professionalism, teacher

\section{Introduction}

The development of technology leads to many significant changes. The science and technology development also change the thinking pattern of people in going through their activities (Budiman, 2017). The change also happened to people idea on education and the learning activity. Science and technology learning can be done anywhere and anytime. As we know, science and technology are very beneficial for education all over 
the world. Education takes a big role in developing human resource quality. However, the development of technology has not been optimally utilized in the education field. According to Benny Kusuma Education Lead of Microsoft Indonesia, the utilization of technology within the education field may only reach $20 \%$ (Novia, 2016).

The revolution and technology development gives the reverse impact on education in Indonesia. We can say that Indonesian education is a wagon of a train which only follows the available railway. However, education is ideally can be a locomotive for the future of human life to be compatible with this revolution. Based on the result of the Programme for International Study Assessment (PISA) in 2012, Indonesia was at the lowest level of education quality (Priansa, 2014). The low level of education quality disables Indonesian to keep up with the revolution and competition with the other countries. Education quality is mainly affected by some factors. The most significant factor is the teacher's ability in implementing curriculum to the learning activities.

Teacher quality significantly affects the accomplishment of the national learning objective. No matter how perfect a program or policy, it will never be well accomplished with the problems along the application. Therefore, the teacher is required to apply the learning program to the students so that it can create an excellent human resource. The other roles of teacher are also explained in the Law number 14 (2005) which mention that "Teacher is the professional educator whose job is to educate, teach, guide, direct, train, assess, and evaluate the students of early childhood education, primary education, and secondary education". Teacher's role also involves the role in building student's character and personality based on the valid norms and values.

The teacher needs a number of competencies to be able in performing the role. Unluckily, most Indonesian teachers have the low quality of competence. It is shown in the UKG or the test on teacher competence which was carried in 2015 by the Indonesian government. The average score of teacher' pedagogical and professional competence was 53.02. It was below the targeted average of 55 (Minister of Education and culture of Indonesia). The administration completion is also a problem for the teacher. There are many teachers who are unable to perform their role as classroom administrator. It is in line with the research from Putri and Imaniyati (2017) which mentioned that teachers did not prepare a lesson plan, ignored teacher administration, did not prepare the wellstructured learning material, and the monotonous learning model and method, and also the less optimum evaluation system.

The low quality of Indonesian teacher added with technology development and revolution lead to the serious problem for education in Indonesia is the teachers are unable to improve and update their competence. Teachers who are unable to improve the 
competence are just the same with when we are replaying the old film during the learning session (Izzan, et.al, 2012). There will be no improvement and update of the given knowledge. From the description, there are related issues: How is the development of professional teacher in the ICT era?, and 2 . What are the factors influence the development of professional teacher?

Professional teacher possesses some characters such as having a commitment with the students and the learning process, mastering the subject and the learning method, have a responsibility to oversee the learning result using various evaluation method, systematically think about planning and introspecting, actively taking part in the professional society environment (Suprihatiningrum, 2013).

The professionalism of a teacher can be shown by the following actions: (1) The enthusiasm to perform at least within the ideal standard; (2) improve and conserve the professional prestige; (3) the desire to improve professional competence along with skill and knowledge of a teacher; (4) the desire to chase quality and idealism in the profession; (5) proud of the own profession (Sagala in Yusutria, 2017).

Teacher as a professional staff may relate to teacher competence, teacher certification, and teacher professional allowance(Priansa, 2014: 108). The first thing to do for the teacher in representing they professionalism is by improving potency and competency. The competence improvement can be seen from its academic qualification for the teacher, which should pass the undergraduate program and possess the competence as a professional teacher (Suprihatiningrum, 2013 \& Lion, 2015).

\section{Methods}

It was a literature study which was done by analyzing theories or empirical result from the previous studies (Sukmadinata, 2013). The data was gained from journals, books, and scientific publication related to the research problems. In analyzing the data, the researchers used document content analysis related to the development of the professional teacher.

\section{Finding and Discussion}

The teacher is a profession which holds the task from some regulations. It implies the strategic task of a teacher in developing students' potencies. The professional teacher existence is strongly linked with the improvement of education quality. It can be seen from the main tasks of a professional teacher, which are educating, teaching, and training 
so that the student's potencies can be developed. The task of a teacher is not merely about delivering the material. Further, the teacher's task and role involve planning a well-structured learning material compiled from the supporting knowledge and science sources. Added with the technology development, it is expected to improve teacher's competence, knowledge, and attitude which are beneficial for the students to keep up with this competitive era.

Therefore, a continuous process to improve and develop teacher's competence in accordance with the technology development is highly needed. It is in line with the research from Kang, Kim, \& You (2012) which explained the shift of academic standard are simultaneous with the ICT improvement and global economic development. As the result, we cannot put off the professional development of teacher anymore.

\subsection{Professional teacher development in the ICT era}

The teacher holds the main role in the whole process of education, especially within the institutional and instructional level. The teacher is the front liner in the education practice. The existence and readiness of a teacher in applying they task play a significant role in the success of the educational process. The teacher is the central and the starting point of the process of educational building. Regarding that, the teacher is in charge to always develop and improve the professionalism through some activities. According to Netolicky (2016), the development of teacher professionalism may be beneficial for being based on motivation, continuous improvement, collaboration, and building the professional learning culture of schools. The development of a professional teacher is not only about improving competence, but also involves motivating the teacher to innovate the learning culture at the school. The development of professional teacher also attracts global attention, as the task of teacher also includes the ability to build the attitude and strong mental of students to face the globalization. The mechanism of professional teacher training in Indonesia may be in a form of further study, in-service training, empowering MGMP or subject teacher forum and KKG or teacher working group, also the teacher competency test.

The development of teacher professionalism may start from the inside. It can be accomplished by improving the professionalism so that the teacher's professionalism meets the standard of the primary and secondary task of a teacher. One of the developments for the teacher is a further study which is aimed to expand the teacher's knowledge. Teacher's school and the government should be able in motivating teacher to go on a further study as the means to develop professionalism. Besides, the teacher 
should also enrich themselves with the knowledge from either printed or online reading materials such as books, journals, and scientific publication about the professionalism of a teacher. The ICT utilization has become a concern in the educational literature as the learning media and strategy to answer the global challenge and improve the experience of the students (Dawson, Heatchote, \& Poole, 2010: 119). The ability to use IT is an obligatory competence for the teacher today.

Teacher professional development can be started form school by creating teachers learning community. According to Sato (2014), building a learning culture using lesson study method enable a teacher to learn together with the other teacher at the school. It is also an activity to stimulate the professionalism and collegiality of teacher. In addition, it can also improve teacher and students cooperation during the learning process (Sato, 2014). The other benefits of these activities are to find out teacher's professional competence, also the strength and weakness of a teacher's competence to be managed during the process of professional development. Therefore, we can observe teacher's planning before the class, the learning activities during the class, and the activities within the teacher's forum to improve the classroom learning process (Yamin\& Maisah, 2010).

Learning culture at school has the same objective as the supervision by the school headmaster. It is supported by a statement of Riva'i (Ermita, 2017) that supervision implementation procedure is made to detect weakness of teacher, and develop the ability possessed by the teacher. It is the essential meaning of the development of professional teacher. Creating learning community at home can be accomplished through 3 activities (Samsudin, 2014) which are preparation or training to form lesson plan by involving ICT to the learning process (see), implementing the lesson plan to the actual learning process (do), and evaluating strength and weakness of the learning activities (plan). There will be follow up for the strength and weakness found in the teacher through training, supervising, and supporting program from the school headmaster to the teacher. The follow-up activities are expected to create an instructional improvement to the learning service and curriculum development.

Teacher group learning activity to visit other schools can be a mean to visit the colleagues and take advantage of in-service training, a program to focus on a new knowledge which may influence educational policy formation. School is able to give chance for the teacher to actively participate in self-improvement regarding the development. During in-service training, there will be training to apply new learning model and approach, writing ability improvement to create scientific paper and improve the ability of the teacher to give excellent training for the student competition. 
Teacher professional development can also be accomplished through MGMP or subject teacher forum and KKG or teacher working group. Subject teacher forum is the periodic activity to discuss problems during the learning process in every respective school regarding the professionalism of a teacher and then other problem as a mean to form solution (Hasanah, 2014). On the other hand, teacher working group or KKG is aimed to improve teacher mastery for the certain subject. The other advantages may involve the improvement on curriculum understanding, improvement of learning quality and giving new knowledge to be applied to the teaching process, and self-improvement activities (Thacker, 2017).

\subsection{The influencing factors of professional teacher development}

Teacher's quality can be done from teacher performance in completing the task. It is in line with Wahyudi's opinion (2012) that teacher's performance is the representation of the quality and quantity of teacher's achievement according to its responsibility. The responsibility means that teacher should be responsible for composing lesson plan, learning media, learning material, and learning method. The other responsibility relates to administration completion to support task completion. The development of teacher professionalism is influenced by two main factors, the internal factor, and external factor. The internal factors involve passion, talent, motivation, openness, while the external factors involve the environment, facility, and the leadership at school Us, 2015; Bernawi \& Arifin, 2012). From all the factors, the most influencing factors are openness and school leadership factors.

The open-minded teacher is needed in order to be able in accepting the development of technology which cannot be avoided. It makes teacher responsive to the shift and improvement, especially the change and improvement which relate to the task of a teacher. The shift may also affect the education and learning paradigm. The shift is mainly contributed by the innovation and the new theory which relates more to today's reality. For example, the new paradigm is the shift of teacher-centered learning to the students centered learning. It emphasizes to students' learning experience where the teacher is just a facilitator who facilitate the learning process using the varied learning methods, ICT based learning media, and the guidance to achieve the learning objective. This way, the openness of a teacher in accepting shift and change motivate the teacher to achieve and develop the possessed competence (Sobirin, 2012).

Leadership at school also influences the professionalism of a teacher (Sobirin, 2012). It relates to the role of headmaster as the manager of the school. The role of school 
headmaster involves interpersonal, information, and decision making. As a manager, the headmaster is expected to be able in maintaining and developing a teacher's professionalism. The development of teacher professionalism by headmaster may in a form of the facilities to get teacher training and education. The teacher can also develop teacher professionalism by giving task for the teacher to be organized effectively. In order to do the task, the headmaster is expected to manage cooperation with the teacher so that learning objective can be effectively accomplished.

Or else, the school can also involve the teacher in the planning and develop the program of the school. It directly affects teacher competence as the headmaster is able to provide space for teacher idea and aspiration in contributing to the school's innovation and well-formed communication among teachers, staffs, and headmaster.

\section{Conclusion and Recommendation}

Technology utilization for professional teacher development is significantly needed as a step taken by the stakeholder in facing the development of the era and technology. The development of technology enables the teacher to develop and improve professionalism quality anytime and anywhere. The teacher is expected to be responsive toward the development and changes that the teacher is able to perform a learning activity which is in line with the development and modernization.

\section{References}

[1] Bernawi \& Arifin, Mohammad. (2012).Kinerja Guru Profesional: Instrumen Pembinaan, Peningkatan, \& Penilaian. Yogyakarta: Ar-Ruzz Media.

[2] Budiman, Haris. (2017). Peran teknologi informasi dan komunikasi dalam pendidikan. Jurnal Pendidikan Islam, 8, 75-83

[3] Dawson, S., Heathcote, L., \& Poole, G. (2010). Harnessing ICT Potential. International Journal of Educational Management, 24 (2), 116-128.

[4] Ermita. (2017).The Effect of Supervision Implementation Towards Teacher Performance at SMKN Business Management Group in Padang City.Educational Administration Review, 1 (1) June 2017

[5] Hasanah, Ulva Uswatun. (2014). Pengaruh Supervisi Akademik dan Kegiatan Kelompok Kerja Guru Terhadap Kinerja Mengajar Guru.Jurnal Administrasi Pendidikan, 21 (2).

[6] Izzan, Ahmad, dkk. (2012).Membangun Guru Berkarakter.Bandung: Humaniora 
[7] Kang, M., Kim, M., Kim, B., \& You, H. (n.d.). (2012) Developing an Instrumen to Measure 21st Century Skills for Elementary Student. The Korean Journal of Eductional Methodolocy Studies, 25(2).

[8] Kemendikbud. (2016). Guru Pembelajar: Pedoman Program Peningkatan Kompetensi. Jakarta: Direktorat Guru dan Tenaga Kependidikan

[9] Lion, Eddy. (2015). Kemampuan Profesional Guru Dalam Pembelajaran Efektif.Jurnal Pendidikan Vol.3(1)

[10] Netolicky, Deborah M. (2016).Rethinking professional learning for teachers and school leaders.Journal of Professional Capital and Community, 1 (4), 270-285, https: //doi.org/10.1108/JPCC-04-2016-0012

[11] Novia, Dyah Ratna Meta. (2016).Penggunaan teknologi dalam dunia pendidikan indonesia. Republika diakses di https://www.republika.co.id/berita/trendtek/ internet/16/05/03/0614t0359-penggunaan-teknologi-dalam-dunia-pendidikanindonesia-masih-rendah

[12] Priansa, Donni Juni. (2014).Kinerja dan Profesionalisme Guru.Bandung: Alfabeta

[13] Putri, Ayu Dwi Kesuma \& Imaniyati, Nani. (2017).Pengembangan Profesi Guru dalam Meningkatkan Kinerja Guru.Jurnal Pendidikan Manajemen Perkantoran, 1 (1), 94-103

[14] Richardo, Rino. (2016).Program Guru Pembelajar: Upaya Peningkatan Profesionalisme Guru di Abad 21.Prosiding Seminar Matematika dan Pendidikan Matematika.ISBN: 978-602-6122-20-9

[15] Samsudin, Achmad. (2014). Supervisi Akademik Pembelajaran IPA Melalui ICT Based Lesson Study Untuk Membangun Learning Community Guru SD.Mimbar Sekolah Dasar vol 11 pp 77-82.

[16] Sato, masaaki. (2014).Lesson Study Untuk Meningkatkan Profesionalisme Guru: Sekolah Sebagai Learning Community.Prosiding Seminar Nasional: Pemantapan Implementasi Kurikulum 2013 dalam Pendidikan Sekolah Dasar

[17] Sobirin. (2012). Faktor-Faktor yang Mempengaruhi Kinerja Mengajar Guru Sekolah Dasar.Jurnal Adminisistrasi Pendidikan Vol.XIV No.1 April 2012

[18] Sukmadinata, N. S. (2013). Dalam Metode Penelitian Pendidikan. Bandung: Remaja Rosdakarya

[19] Suprihatiningrum, Jamil. (2013).Guru Profesional: Pedoman Kinerja, Kualifikasi, \& Kompetensi Guru.Jogjakarta: At-Ruzz Media.

[20] Thacker, Emma S. (2017). "PD is where teachers are learning!" high school social studies teachers' formal and informal professional learning. The Journal of Social Studies Research, 41, 37-52. http://dx.doi.org/10.1016/j.jssr.2015.10.001 
[21] Undang-Undang Republik Indonesia Nomor 14 Tahun 2005 tentang Guru dan Dosen

[22] Us, Kasful Anwar. (2015). Jaminan Mutu dan Upaya Pengembangan Profesionalitas Guru Pada Abad Pengetahuan.Jurnal Nur El-Islam, 2 (2)

[23] Wahyudi, Imam. (2012).Mengejar Profesionalisme Guru: Strategi Praktis Mewujudkan Citra Guru Profesional.Jakarta: Prestasi Pustaka

[24] Yamin, Martinis \& Maisah. (2010).Standarisasi Kinerja Guru.Jakarta: Gaung Persada Press.

[25] Yusutria. (2017). Profesionalisme Guru Dalam Meningkatkan Kualitas Sumberdaya Manusia. Jurnal Curricula Kopertis Wilayah X, 2(1) 